\title{
European Identity and its Relationship to National and Ethnic Identities among Younger and Older Members of Ethnic Minority Groups
}

Natalia Waechter ${ }^{1}$ - Evgenia Samoilova ${ }^{2}$

University of Graz, Austria, and Leibniz-Institut für Sozialwissenschaften (GESIS), Cologne, Germany

\begin{abstract}
European Identity and its Relationship to National and Ethnic Identities among Younger and Older Members of Ethnic Minority Groups. European identity is neither a new phenomenon nor a new concept. Yet, after almost three decades of research, this area is characterized by a wide variety of concepts and little empirical evidence. Existing studies in the area propose homogeneous concepts of societies and often disregard European identity among ethnic minorities and non-citizens. This paper addresses the gap in the literature and analyses European identity among 12 minority groups living in Central and Eastern European (CEE) countries that have already become or might become EU members. The purpose of this study is to examine the choice of European identity and attitudes towards Europe in relation to other identities among respondents with an ethnic minority background. The paper addresses this question within the life-course perspective and examines differences in identity levels between the young and older cohorts of minority groups. For our analysis we have used a sample of 6800 members of ethnic minorities living in CEE (ENRIValues and Identities Survey). Our results indicate a stronger level of European orientation among minority young people in comparison to adults. Moreover, the study shows that while young minority cohorts manifest stronger levels of European identity than adults, their levels of national and ethnic identity are significantly lower. While adults consider their national identity to be more salient than European identity, young people give the two equal degrees of importance. At the same time, for both young people and adults, the results illustrate that European identity is compatible with both national and ethnic identities.
\end{abstract}

Key words: identity, ethnic minority, young people, European identity, attitudes towards Europe, Central and Eastern Europe, ENRI-East

Európska identita a jej vzt'ah $\mathbf{k}$ národným a národnostným identitám medzi mladšími a staršími príslušníkmi národnostných menšín. Európska identita nie je ani nový fenomén, ani nový koncept. Napriek tomu, po takmer tridsiatich rokoch, charakterizuje túto oblast' množstvo konceptov a málo empirických dôkazov. Jestvujúce štúdie $v$ tejto oblasti ponúkajú homogénne koncepty spoločností a

1 Address: Natalia Waechter, University Graz, Department of Educational Science, 8010 Graz, Merangasse 70, Austria. E-mail: natalia.waechter@uni-graz.at

2 Address: Evgenia Samoilova, Leibniz Institute for Social Science (GESIS), 50667

Köln, Unter Sachsenhausen 6, Germany. E-mail: evgenia.samoilova@gesis.org

Slovak Journal of Political Sciences, Volume 14, 2014, No. 2

DOI: $10.2478 /$ sjps-2014-0005 


\begin{abstract}
často neberú do úvahy európsku identitu medzi národnostnými menšinami a cudzincami. Táto štúdia sa zaoberá medzerou $v$ literatúre a analyzuje európsku identitu medzi 12 národnostnými skupinami $v$ krajinách strednej a východnej Európy, ktoré sa už stali alebo mohli by sa stat' členmi Európskej únie. Účelom tejto štúdie je preskúmat' vol'bu európskej identity a postoje k Európe vo vzt'ahu $\mathrm{k}$ iným identitám medzi respondentmi, ktorí majú pôvod v národnostnej menšine. Štúdia sa zaoberá touto otázkou v rámci životnej perspektívy a skúma rozdiely $v$ úrovni identity medzi mladšími a staršími príslušníkmi menšinových skupín. Vo svojej analýze sme použili vzorku z 6800 príslušníkov národnostných menších žijúcich v strednej a východnej Európe. Naše výsledky naznačujú vyššiu úroveň európskej orientácie medzi mladšími l'ud'mi z národnostnej menšiny v porovnaní s dospelými. Okrem toho táto štúdia ukazuje, že kým mladší príslušníci národnostnej menšiny dávajú najavo vyššie úrovne európskej identity než dospelí, ich úrovne národnej a národnostnej identity sú preukazne nižšie. Zatial' čo dospelí sa domnievajú, že ich národná identita je význačnejšia než európska, mladší ludia udávajú dva rovnaké stupne dôležitosti. Výsledky $v$ prípade mladých l'udí a dospelých zároveň ukazujú, že európska identita je kompatibilná s národnými aj národnostnými identitami.
\end{abstract}

Kl'účové slová: identita, národnostná menšina, mladí l'udia, európska identita, postoje k Európe, stredná a východná Európa, ENRI-Východ

\title{
1. Introduction and research question
}

Until recently, the "European project" has been considered primarily to be a subject of political elites. Nevertheless, such developments as the failure of European constitutional referenda, low voter turnout in European elections, as well as increasing fears of migration movements of Eastern Europeans, suggest that there is an urgent need for an adequate democratic legitimation of the European Union (EU). Interestingly, the discussion of the democratic shortcomings touches not only upon institutional aspects of giving more power to the European Parliament, but also emphasizes existence of a European community with a shared collective European identity (Deutsch, 2006).

While the belief that a common European identity is essential for the legitimation of EU actions is widespread in both political and academic literature (Fossum, 2001; Herrmann \& Brewer, 2004; Karolewski \& Kaina, 2006; Kraus, 2008; Mach \& Pozarlik, 2008), the questions of what European identity constitutes and how it should be approached are open and still disputed.

This paper is not aimed at further exploring the conceptual intricacy of European identity. It rather points to existing gaps in the current empirical literature and suggests the importance of ethnic background and birth cohort in studying European identity.

Studies on European identity mostly agree that European identity is one of several possible social identities of an individual. In other words, social identities are plural and not necessarily incompatible with each other. One of 
the most common questions in the current literature on the topic addresses the relation between European and national identity. The results so far are not uniform and indicate different trends. However, the general inclination of these studies is that national identity tends to be stronger than European identity and in some cases is negatively correlated with it (Cinnirella \& Hamilton, 2007; Deutsch, 2006; Kraus, 2008).

With the exception of a few studies, there has been a tendency to treat all citizens as a homogeneous community disregarding the existence of citizens of an ethnic minority as well as different birth cohorts and generations. Based on the assumption that an ethnic background as well as birth cohort constitutes an important variable in studying European identity, we address two questions: Is there a difference in the level of European identity between younger and older cohorts? How do the two cohorts manage and reconcile their multiple identities, i.e. European, national, and ethnic identities?

All results are based on a social survey aimed at 12 minority groups in eight countries and conducted within the ENRI-East project - European, National, and Regional Identities (http://www.enri-east.net), an FP7-SSH collaborative research project $(2008$ - 2011) funded by the European Commission under the 7th Framework Programme ${ }^{3}$.

\section{State of the art}

\subsection{Managing multiple identities}

In the research on identity and nationalism, several authors have discussed the diverse uses of the term "identity" (e.g. Brubaker \& Cooper, 2000; Hall \& Du Gay, 1996; Jenkins, 1996). Summarizing the discussion, the overall trend to constructivist theories in the social sciences also influenced the concepts of identity. The previously predominating concepts of identity, that are now called "strong" concepts, have been replaced by the "weak" versions. These "weak", "fluid" or "flexible" versions of identity do not assume a fundamental and durable sense of self-hood, but stress fluidity, impermanence, and context sensitivity of identities. It is assumed that identities are constructed in multiple ways and that the process of identity construction is never completed. They are parts of an ongoing process of emerging, changing and redesigning. The "weak" concept considers identities not as a state but as a process, and it stresses that individuals have multiple or hybrid identities. Applying this concept to territorial identity, the "flexible" approach means that there are several territories that people can feel attached to at the same time.

\footnotetext{
${ }^{3}$ Further results of the research project ENRI-East have been published in 2011 in the special issue of the Slovak Journal of Political Sciences 11(3)
} 
This aspect of the multifaceted nature of identity has attracted considerable attention. The literature on the compatibility of various forms of identity consists of opposing views. Some authors suggest that an individual cannot have compatible attachments to more than one community. In other words, an individual can have only one collective identity, which would conflict with all other possible attachments (Tajfel, 1981, Tajfel \& Turner, 1986). Another, more common view is that an individual can manifest and manage multiple identities given that they are not conflicting with each other (Hofman, 1988). For instance, Hofman suggested a typology of identity construction. He proposed three possible relationships between social identities. Identities can be compatible, unrelated, or incompatible (Hofman, 1988). In light of our research interest, the third approach would suggest that European identity is possible only at the expense of other collective identities such as a national and ethnic sense of belonging. The first approach would suggest that the compatibility of European, national and ethnic identities is not only possible, but that these identities can also reinforce each other.

In studying the compatibility of European identity with other attachments, empirical research has primarily focused on the majority population. Cinnirella (1997) explored the aspect of compatibility in a sample of British and Italian students. He found that while the British and European identity measures are negatively correlated, the Italian and European identities have positive correlation. Fuss and Grosser (2006) have found significant positive correlation between national and European identities in a sample of young people in 10 European countries. However, with few exceptions the studies have focused exclusively on the majority population disregarding heterogeneous composition of current societies in Europe.

Cinnirella \& Hamilton (2007) have shed some light on managing multiple identities among ethnic minorities. In their study, the authors discovered a significant difference in identities and attitudes towards the EU between the indigenous white British respondents and the South Asian minority group. While the majority population reported a negative correlation between national and European identities, the minority respondents manifested a positive relation between the two. At the same time, a generation effect as well as correlation between ethnic and European identity among the minority group proved to be insignificant. Another study (Machácek, 2012) focuses on the Hungarian minority living in Slovakia. The author also shows that members of the analyzed minority group apply multiple identities. Furthermore, the younger generation reported a more positive assessment of the EU than older generations.

While the studies by Cinnirella \& Hamilton (2007) and Machácek (2012) have pointed out the importance of considering ethnic minorities in the study of 
European identity, both are limited to one country and a small sample size. Our paper aims to fill the gap by considering the interplay between different collective identities among minority groups in Europe with a sufficient sample of 6,800 respondents.

\subsection{Salience of European identity}

The fact that identities can be compatible does not mean that they have an equal degree of salience for individuals. It has become common to acknowledge that individuals have only one "self", but several aspects of identity, with some aspects becoming primary. Such primary aspects of identity are gender, age, religion or nation, whereas European identity is not considered likely to be integrated into individuals' primary identity aspects (Bauböck, 2000). Research on territorial identities with young people shows that European identity is the least important identity compared to their identification with a city, country or region of residence or origin (Jamieson, 2005; Machácek, 2004; Spannring et al., 2005). One plausible explanation is that people are likely to negotiate identity in day-to-day interactions, and since European identity is not often present in individuals' interactions, people are not likely to identify with Europe (Spannring et al., 2005).

Results from an international research project ("Youth and European Identity") show that only a small proportion of young people have developed a strong European identity. There seem to be regional differences regarding the level of identification with Europe, ranging from less than a quarter to around a half claiming a European identity. It is predominantly the group of the welleducated and qualified young people, those who can speak foreign languages, travel a lot and/or come from a family with a migration background (Jamieson, 2005). The project also found that geography and the political alliance of the EU were important to more respondents than values or the economic alliance expressed by the euro. However, they did not confine the geography of Europe to the EU. Defining Europe in contrast to Asia, America and the Islam, it seemed to be easier for the respondents to determine what Europe is not than what it is (Jamieson, 2005).

Although European identity is not found to be a prevailing aspect of identification, some comparative studies provide interesting insight into identity construction processes. Cinnirella \& Hamilton (2007) have shown that while the indigenous white British respondents indicated a weaker European identity in comparison to a stronger national identity, the South Asian respondents put ethnic identities in first place, followed by British and European identities respectively.

International research on European identity also shows that younger members of the population are more likely to identify with Europe and the EU 
than the older population. Regarding age, one of the main results of the Eurobarometer (2005) is that the older the respondents, the more likely they feel only as citizens of their country and not as citizens of Europe. The younger they are, the more likely they can imagine being citizens of their own country and citizens of Europe at the same time. However, among those aged 15 to 39, this only applies to around $50 \%$ of the respondents. The respondents aged younger than 24 are most likely to be proud of being European (74\%). They are also most familiar with the European flag. Furthermore, they are more likely to wish for faster development in building up Europe. At the same time they seem to be more critical towards unequal development in different countries. They would prefer all countries to develop with the same speed. In general, they are less concerned about all possible worries usually connected with the EU. However, $50 \%$ or more are worried about the following items: the shift of production sites to countries where production costs are cheaper, the rise of drug trafficking and international organized crime, more difficulties for national farmers, national payments to the $\mathrm{EU}$, and the end of the national currency (Eurobarometer, 2005).

So far, no international comparative research on European identity has been carried out that would have focused on young people belonging to ethnic minority groups. In this contribution, we address this gap by examining the salience of European identity between younger and older cohorts of the respondents with an ethnic minority background.

\section{Hypotheses}

Our broad goal is to assess differences in European identities and attitudes towards Europe among the two birth cohorts of ethnic minorities. Even though many young people in the age group between 18 and 29 may regard themselves as adults, there is an overall European trend of a prolongation of the youth phase due to social and economic changes such as more years of education, difficulties entering the labour market, (see Waechter, 2012). In this respect we think it is appropriate to still refer to this age group as the "young cohort". For our minorities researched in Eastern and Central European countries, belonging to the "young cohort" has an additional meaning: They belong to the first generation which has experienced their youth in a post-communist regime. Most of them were still born in the communist era, but have already been politically socialized into the new regime. In this paper, we will use the terms "young" and "older cohort" and young people and adults interchangeably.

Based on the indicated cohort differentiation, we expect younger minority members who have been born and socialized into a post-communist period, which in some countries coincided with receiving their independence, are often viewed as being suspended between two cultures and holding both national and 
ethnic identities. Therefore, young cohorts are more likely to place themselves in broader categories such as identifying as European. Research on European identity among majority groups also shows that the younger population is more likely to identify with Europe and the EU than the older population. Therefore we can hypothesize as follows.

Hypothesis A: We expect young people in ethnic minorities to manifest a significantly stronger level of European identity than ethnic minority adults.

Sub-hypothesis A1: We expect young people of ethnic minorities to consider European identity more vital to their self-hood than ethnic minority adults.

Sub-hypothesis A2: We expect young people of ethnic minorities to feel closer to Europe than ethnic minority adults.

Sub-hypothesis A3: We expect young people of ethnic minorities to be more proud of being European than ethnic minority adults.

Sub-hypothesis A4: We expect young people of ethnic minorities to have (a) a more positive image of and (b) more positive attitudes towards the EU than ethnic minority adults.

Sub-hypothesis A5: We expect young people of ethnic minorities to be more inclined to perceive benefits for their countries from being EU member than ethnic minority adults.

Some studies (e.g. Örkény \& Sik, 2011) have shown that national identity may be different in importance and composition for minorities in comparison to majority populations. Minorities may have a much weaker national identity, regard it as less important, or base their national identity on different associations and memories. If national identity is less important and different in its content for minorities, then we might expect that there is either no or a positive relation between national and European identities.

Hypothesis B: We expect either a non-significant or positive correlation between national and European identity among members of ethnic minority groups.

Existing literature brings no strong reasons to suggest that European identity imposes a threat towards ethnic identities of the minority groups. In contrast, the concept of European citizenship as well as the freedom of movement within the EU creates a positive context for ethnic minorities. In addition, groups with a strong sense of ethnic belonging may find it easier to relate to a supranational polity such as the EU rather than a nation-state, which is often based on an exclusive understanding of the past.

Hypothesis $\boldsymbol{C}$ : We expect a positive correlation between ethnic and European identity among members of ethnic minority groups. 


\section{Methodology}

All data used for writing this article is from the ENRI Values and Identities Survey (ENRI-VIS) as it was collected in the ENRI-East project. The survey aims at being representative for all individuals belonging to the surveyed ethnic minority groups aged 18 and older, residing in private households in the surveyed country for at least one year at the time of the interview, regardless of their citizenship status and/or language spoken. Furthermore, the interviewees had to identify themselves as members of a researched ethnic minority group. The survey was not specific to young people and covered several aspects of territorial identities including national, ethnic and regional identities (Waechter \& Samoilova, 2012).

The survey was carried out between December 2009 and February 2010 for all ethnic minority groups except Belarusians in Lithuania where the field work had to be postponed due to the severe winter. All interviews were carried out face-to-face in the language spoken by the respondent.

ENRI-VIS focused on ethnic minority groups in Eastern European countries which, usually due to migration flow as well as shifting borders, have established diverse ethnic populations. The survey covers 12 minorities from eight countries; for each country the largest ethnic minority/minorities have been taken into account (see Table 1).

Table 1: Ethnic minority group population statistics selected for ENRI-VIS

\begin{tabular}{llcc}
\hline Minority ethnic group & Country of residence & $\begin{array}{c}\text { Size (official } \\
\text { data) }\end{array}$ & $\begin{array}{c}\text { Proportion (\%) of total } \\
\text { population (official } \\
\text { data) }\end{array}$ \\
\hline Russian & Latvia & 703,243 & 29.6 \\
Hungarian & Slovak Republic & 514,235 & 9.5 \\
Polish & Belarus & 396,712 & 3.9 \\
Polish & Lithuania & 234,989 & 6.7 \\
Russian & Lithuania & 219,839 & 6.3 \\
Hungarian & Ukraine & 156,566 & 0.3 \\
Polish & Ukraine & 144,130 & 0.3 \\
Belarusian & Poland & 47,640 & 0.1 \\
Belarusian & Lithuania & 42,866 & 1.2 \\
Slovak & Hungary & $17.693(39,266)$ & 0.4 \\
Ukrainian & Poland & 27,172 & 0.1 \\
Lithuanian & Russia (Kaliningrad) & 17,700 & 1.9 \\
\hline
\end{tabular}

Official data are taken from the latest available official sources (census) in each country. Data in parentheses for the Slovakian minority in Hungary are based on expert estimates.

ENRI-VIS used two different target sample sizes: larger samples with 800 respondents for those ethnic minority groups which constitute either a significantly large population or a considerable share of a country's total 
population, and smaller samples with 400 respondents for ethnic groups regarding their number and their density. The top five in Table 1 were considered large minorities $(n=800)$.

The survey was not carried out across the whole of each country; we selected those regions which showed the highest density rate of the ethnic minority group among the total population. Depending on the size of that density in the selected regions, three different sampling methods were applied: random route sampling (RRS), random route sampling boosted by focused enumeration (RRFE), and snowball sampling strategies:

1. In areas where the ethnic minority constituted $30 \%$ or more of the total population, ENRI-VIS applied a random sample using random route procedures within its primary sampling units (RRS). Interviewers started their field work at randomly selected starting addresses and continued to approach households by following pre-defined route patterns.

2. In areas where the ethnic minority constituted between $10 \%$ and $29.99 \%$, ENRI-VIS also used RRS but boosted these with RRFE. That is, ENRI-VIS also contacted households neighbouring the one initially identified by the random routes and identified eligible individuals there.

3. In areas where ethnic groups constituted less than $10 \%$ of the total population, ENRI-VIS did not use random mechanisms, but instead used snowballing techniques (respondents proposing other respondents) due to the anticipated low response rate. In order to enhance diversity in the snowball sample we have used different starting points for snowball chains (such as known individuals and institutional actors/contact centres).

The sampling method chosen for each region depended on the density of the ethnic minority. The snowballing technique had to be applied in certain regions for Slovakians in Hungary, Belarusians in Lithuania, Ukrainians in Poland, Lithuanians in Russia, and Poles in Ukraine. Sampling methods were not allowed to be mixed within individual regions. Starting addresses for RRS and RRFE were drawn randomly from available complete address registers. The number of starting points was proportional to the density of the ethnic minority group among the total population in that region.

The questionnaire included many questions from other big surveys, such as the European Value Survey (EVS), the World Value Survey (WVS), or the Eurobarometer. For the specific topic of European identity, questions were borrowed from the International Social Survey Programme (ISSP) and the Eurobarometer 62.0.

\section{Sample description ENRI-VIS}

From our total sample $(n=6,800)$ almost 1,000 belong to the younger cohort ( $n$ $=995$ ). In the questionnaire, we have only asked for the year of birth, and since 
most of the data collection took place at the beginning of 2010, we do not have many 18 year olds in our sample (18 or older was one of the requirements for eligibility). Other than that, we have an equally distributed sample of young people in terms of year of birth (1981-1991). We have different sample numbers for each minority for the young cohort and the 12 ethnic minorities researched (see Table 2).

Table 2: Sample sizes

\begin{tabular}{lcc}
\multicolumn{1}{c}{ Ethnic minorities } & \multicolumn{2}{c}{ Sample sizes } \\
& 18-29 year olds & 30 years and older \\
\hline Russians in Latvia & 153 & 647 \\
Russians in Lithuania & 150 & 648 \\
Hungarians in Slovakia & 109 & 690 \\
Poles in Belarus & 103 & 696 \\
Poles in Lithuania & 96 & 718 \\
Lithuanians in Russia & 96 & 305 \\
Hungarians in Ukraine & 80 & 318 \\
Poles in Ukraine & 71 & 325 \\
Belarusians in Lithuania & 57 & 342 \\
Ukrainians in Poland & 52 & 337 \\
Belarusians in Poland & 21 & 379 \\
Slovaks in Hungary & 7 & 400 \\
Total & 995 & 5,805 \\
\hline
\end{tabular}

The different numbers result partly from the diverse age distributions within the whole population of those ethnic groups and partly because of difficulties in data collection. Some ethnic minorities tend to lack young people (especially true for Slovaks in Hungary). Typically, they live in rural, less developed areas where mostly older people have stayed. Furthermore, young people are more mobile and hard to reach at home for a personal face-to-face interview. For overall analysis we included all ethnic groups regardless of their individual sample size. For comparative analysis (between ethnic groups), we did not consider Slovaks in Hungary and Belarusians in Poland because of their small sample sizes for young people.

For the sample of young people the gender distribution is more equal than for the whole sample; $56.2 \%$ are young women compared to $43.8 \%$ young men (Waechter \& Samoilova, 2012). ${ }^{4}$ For some ethnic groups the gender distribution among the young cohort tends to be equal (Poles in Ukraine, Belarusians in Poland, Hungarians in Slovakia, Ukrainians in Poland), and for

\footnotetext{
${ }^{4}$ In the adult group there are $63.2 \%$ women and $36.8 \%$ men. Again, that unequal distribution results from women being more at home (and therefore being more available for questioning) and from having an unequal gender distribution in the whole population.
} 
some ethnic groups it tends to be as unequal as it is for the whole adult sample (Poles in Lithuania, Russians in Lithuania, Poles in Belarus).

Regarding educational background, we created three groups (primary, secondary and tertiary education) according to the highest level of education the respondents achieved: the majority completed secondary education $(64.0 \%)$, a third completed tertiary education $(34.1 \%)$ and only $1.3 \%$ achieved no more than primary education (Waechter \& Samoilova, 2012).

\section{Results}

\subsection{European identity in first, second and third choice of respondents}

In order to identify the relevance of European identity within the whole set of individual aspects of identity, we asked the respondents what is most important to them in describing who there are. They were asked to check their first three choices. First, we looked at the results by the first, second and third choice. Among the young cohort (see Table 3a), their most important first choice identification items are gender, occupation and age group. Their most often checked second choice identification items are age, gender and being a member of their ethnic minority group. Finally, their most important third choice items are age, their settlement, and being a member of their ethnic minority group. The older cohort (see Table 3b) showed much stronger identification with ethnic identity. Their most important first choice identification items are occupation, ethnic minority group, and gender. Their most often checked second choice identification items are ethnic group, religion, and gender. Their most important third choice items are their settlement, ethnic minority group, and age group.

Interestingly, the older cohort also showed higher identification with their country of residence: $6.47 \%$ of the older cohort have chosen national identity as their first choice, $7.5 \%$ as their second choice, and $11.71 \%$ as their third choice in comparison to $5.64 \%, 4.84 \%$, and $8.78 \%$ among the young cohort.

Table 3a: What is the most important to you in describing who you are? Responses from 18-29 year olds

\begin{tabular}{lccc}
\hline & First choice & Second choice & Third choice \\
\hline My gender & $207(22.90 \%)$ & $125(13.83 \%)$ & $91(10.07 \%)$ \\
My current occupation & $201(22.23 \%)$ & $117(12.94 \%)$ & $93(10.29 \%)$ \\
My age group & $137(15.15 \%)$ & $196(21.68 \%)$ & $129(14.27 \%)$ \\
Being [ethnic minority group] & $92(10.18 \%)$ & $122(13.74 \%)$ & $96(11.24 \%)$ \\
My settlement & $71(7.85 \%)$ & $65(7.19 \%)$ & $118(13.05 \%)$ \\
My religion & $62(6.86 \%)$ & $81(8.96 \%)$ & $65(7.19 \%)$ \\
My social class & $54(5.97 \%)$ & $87(9.62 \%)$ & $94(10.40 \%)$ \\
Being a citizen of [resident country] & $51(5.64 \%)$ & $43(4.84 \%)$ & $75(8.78 \%)$ \\
Being European & $26(2.88 \%)$ & $47(5.29 \%)$ & $72(8.43 \%)$ \\
My preferred political party, group... & $3(0.33 \%)$ & $5(0.55 \%)$ & $21(2.32 \%)$ \\
\hline
\end{tabular}

Slovak Journal of Political Sciences, Volume 14, 2014, No. 2 
$\mathrm{n}=904$.

Table 3b: What is the most important to you in describing who you are? Responses from 30 year olds and over

\begin{tabular}{lccc}
\hline & First choice & Second choice & Third choice \\
\hline My current occupation & $1034(19.12 \%)$ & $514(9.51 \%)$ & $475(8.79 \%)$ \\
Being [ethnic minority group] & $1007(18.62 \%)$ & $1050(20.03 \%)$ & $670(13.25 \%)$ \\
My gender & $851(15.74 \%)$ & $635(11.74 \%)$ & $478(8.84 \%)$ \\
My religion & $711(13.15 \%)$ & $788(14.57 \%)$ & $482(8.91 \%)$ \\
My settlement & $615(11.34 \%)$ & $730(13.50 \%)$ & $995(18.40 \%)$ \\
My age group & $484(8.95 \%)$ & $589(10.89 \%)$ & $600(11.10)$ \\
Being a citizen of [resident country] & $350(6.47 \%)$ & $393(7.50 \%)$ & $592(11.71 \%)$ \\
My social class & $262(4.85 \%)$ & $372(6.89 \%)$ & $350(6.47 \%)$ \\
Being European & $84(1.55 \%)$ & $139(2.65 \%)$ & $252(4.98 \%)$ \\
My preferred political party, group... & $9(0.17 \%)$ & $31(0.57 \%)$ & $162(2.30 \%)$ \\
\hline
\end{tabular}

$\mathrm{n}=5407$

Regarding their territorial identities, being European does not stand out as the most frequent aspect of core identity either among adults, or among young people. However, more young people identify with Europe in their first, second, and third choice than adults. In addition, in their second and third choice there are almost equal numbers of young people identifying with their country of residence and Europe. In the adult sub-sample, the difference in frequencies between those who have chosen national and European identities as their first, second, and third choice is quite large.

Comparison of the means of the place given to European, national and ethnic identities among the younger and older cohorts (where the score of 1 is for the first choice, 2 for the second and 3 for the third) support the results described above. The means for ethnic, national and European identities among adults (older than 29) are $0.47,0.23$, and 0.08 respectively. For young people (18 to 29 ), the figures are respectively $0.31,0.17$, and 0.15 .

First, in order to measure significance of the difference within the groups, we have conducted Friedman's ANOVA due to violations of normal distribution. In the adult sample, Friedman's ANOVA showed significant difference among the identity score $\left(X^{2}(2)=2142.081, \mathrm{p}<0.001\right)$. Wilcoxon test confirmed significance of the difference between the all three identity scores $(p<0.001)$. A Bonferroni correction was applied and so all effects are reported at a 0.0167 level of significance. Thus, adults consider their ethnic identity more important to their self-hood, followed by national and European identities.

The same tests for the minority youth sample showed that overall identity scores differed $(\mathrm{X} 2(2)=94.047, \mathrm{p}<0.001)$. However, Wilcoxon test revealed interesting results. While European and ethnic identities, as well as ethnic and national identities were found to be significantly different $(p<0.001)$, the 
difference between national and European identities was not significant $(\mathrm{p}=$ $0.126, \mathrm{z}=-1.530$ ). This allows us to conclude that the minority young people in our sample assigned equal importance to both European and National identities.

When we compared the identity scores between the two samples, we found that identities were overall significantly affected by belonging to a particular cohort $(\mathrm{H}(1)=17.823, \mathrm{p}<0.001)$. The follow up post hoc tests showed that young people and adults significantly differ in their degrees of European $(\mathrm{U}=$ $2703437.500 \mathrm{p}<0.001)$, national $(\mathrm{U}=2714347.500 \mathrm{p}<0.001)$, and ethnic identities $(\mathrm{U}=2431422.500)$. In other words, national and ethnic identity is significantly less salient for young members of minorities than for adult members. At the same time European identity is more salient for the younger cohorts than for the older cohort. The latter confirms our first hypothesis A1.

\subsection{Feeling of closeness to Europe}

In this section we are interested in how close respondents feel towards Europe. In addition, we compare it with respondents' feeling of closeness to their ethnic group and country of residence. The set of questions included the Likert-type social identity measures relating to how close respondents feel to Europe, their minority group, receiving country, sending country, region, and Eastern Europe $(1=$ very close, $2=$ rather close, $3=$ rather not close, and $4=$ not close at all). Descriptive statistics indicate that young people hold a stronger sense of European identity but lower sense of both national and ethnic identity than adults; $15.5 \%$ and $38.2 \%$ of young people indicated that they feel very close and rather close to Europe respectively. Among adults, $13.25 \%$ feel close and $34.98 \%$ feel rather close to Europe. While $16.67 \%$ of young people do not feel at all close to Europe, this number is $22.18 \%$ among adults.

Table 4: How close do you feel to Europe, ethnic minority, receiving country?

\begin{tabular}{lcc}
\hline Feeling very close to... & Young people & Adults \\
\hline Europe & $15.5 \%$ & $13.25 \%$ \\
Ethnic minority & $35.89 \%$ & $44.31 \%$ \\
Receiving country & $35.32 \%$ & $45.83 \%$ \\
\hline
\end{tabular}

Differences between adults and young people also appeared when we compared their means. The younger group showed a stronger sense of European identity (mean $=2.48, \mathrm{SD}=0.942, \mathrm{p}<0.001$, one-tailed) than the adults (mean $=2.61, \mathrm{SD}=0.973$ ) which confirms our hypothesis A2. At the same time, the younger group showed a significantly weaker sense of ethnic identity $($ mean $=1.89)$ than adults $($ mean $=1.72, \mathrm{p}<0.001$, two-tailed) and a weaker sense of national identity (mean $=1.87$ for young people, mean $=1.68$ 
for adults, $\mathrm{p}<0.001$, two-tailed). In contrast to the previous section's results, the younger group scored significantly higher on closeness to a receiving country than to Europe $(p<0.001)$, and to ethnicity than a receiving country ( $p$ $<0.01$ )

We have also found out that among both the youth and adult groups individuals with tertiary education report a higher sense of European identity than individuals with secondary education (mean difference $=0.10, \mathrm{p}<0.05$ ). As to gender, female respondents tend to have a slightly higher sense of European identity than male respondents (mean difference $=0.053, p<0.01$, two-tailed). Correlation of European identity with age did not prove to be significant $(\mathrm{r}=0.004, \mathrm{p}=0.758)$.

\subsection{European pride}

We also asked the respondents to estimate how proud they are of being European $(1=$ very proud, $2=$ rather proud, $3=$ rather not proud, $4=$ not proud at all), regardless of their resident country's actual EU membership. The majority of the young people $(68.3 \%)$ reported to be very proud $(20.6 \%)$ or rather proud $(47.7 \%)$ which shows that more young people report being proud of being European than having a positive image of the EU. Again, the young cohort displays a more Europe-oriented attitude: they report a higher score of European pride than the older cohort (59.3\%) (mean for young people $=2.26$, mean for adults $=2.48, \mathrm{p}<0.001$, one-tailed) which confirms our hypothesis A3. Interestingly, both young people and adults manifest significantly higher levels of European pride than national pride $(p<0)$. For the two samples, the highest level of pride is concentrated in the feeling of ethnic pride, although the mean difference is bigger for the youth sample.

Across the whole sample we have found differences in the feelings of pride depending on belonging to a particular ethnic minority groups (Table 5). Among the younger cohort, two clusters of minority groups can be distinguished: seven groups showing strong European pride (more than 65\% very proud or rather proud; see the dark grey boxes in Table 5), and three groups having less pronounced European pride (less than $50 \%$ very proud or rather proud; see the mid grey boxes in Table 5). Within the first cluster, Hungarians in Slovakia, Poles in Ukraine and Ukrainians in Poland express the strongest feelings of European pride (more than $80 \%$ very proud or rather proud). The majority of Belarusians in Lithuania and Poles in Lithuania have similarly strong feelings of European pride, while fewer Russians in Lithuania and Poles in Belarus report being proud of being European (still more than $65 \%$ ). The second cluster consists of Russians in Latvia, Hungarians in Ukraine, and Lithuanians in Russia. The majority of the young people of these 
ethnic minorities report being not (or being rather not) proud of being European.

For the adult cohort, the two clusters are valid as well, but they differ less than those of the young generation: the cluster of those being proud includes ethnic minority groups with more than $50 \%$ reporting European pride. The clusters contain the same ethnic minority groups except for Hungarians in Ukraine who showed a clear cohort difference with the majority of the youth cohort reporting not being proud, the majority of the adult generation reports being proud of being European (see light grey boxes in Table 5).

Table 5: How proud are you of being European?

\begin{tabular}{|c|c|c|c|c|c|c|c|c|c|c|}
\hline \multirow[b]{2}{*}{ Age } & \multicolumn{2}{|c|}{ Very proud } & \multicolumn{2}{|c|}{ Rather proud } & \multirow{2}{*}{$\begin{array}{c}\text { Rather } \\
\text { proud }\end{array}$} & \multirow{2}{*}{$\begin{array}{r}\text { not } \\
30+ \\
\end{array}$} & \multicolumn{2}{|c|}{$\begin{array}{l}\text { Not proud at } \\
\text { all }\end{array}$} & \multicolumn{2}{|l|}{ total } \\
\hline & 18-29 & $30+$ & $18-29$ & 30+ & & & $18-29$ & 30+ & 18-29 & $30+$ \\
\hline Russians in LV & 11.4 & 8.7 & 36.0 & 30.6 & 32.4 & 27.5 & 21.9 & 33.2 & 100 & 100 \\
\hline $\begin{array}{l}\text { Belarusians } \\
\text { in LT }\end{array}$ & 23.2 & 14.0 & 69.6 & 50.05 & 5.4 & 23.1 & 1.8 & 12.5 & 100 & 100 \\
\hline Russians in LT & 23.9 & 13.9 & 48.5 & 39.3 & 20.1 & 21.3 & 7.5 & 25.5 & 100 & 100 \\
\hline Poles in LT & 15.3 & 14.2 & 65.9 & 41.5 & 11.8 & 25.9 & 7.1 & 18.4 & 100 & 100 \\
\hline $\begin{array}{l}\text { Hungarians } \\
\text { in UA }\end{array}$ & 12.7 & 18.7 & 36.6 & 48.9 & 32.4 & 19.2 & 18.3 & 13.2 & 100 & 100 \\
\hline Poles in UA & 40.0 & 30.4 & 55.4 & 59.0 & 3.1 & 9.5 & 1.5 & 1.1 & 100 & 100 \\
\hline $\begin{array}{l}\text { Ukrainians } \\
\text { in PL }\end{array}$ & 30 & 31.4 & 54 & 53 & 14 & 14 & 2 & 1.6 & 100 & 100 \\
\hline $\begin{array}{l}\text { Lithuanians } \\
\text { in RU }\end{array}$ & 12.3 & 10.5 & 35.6 & 35.8 & 37 & 38.9 & 15.1 & 14.7 & 100 & 100 \\
\hline Poles in BY & 13.9 & 11.6 & 51.4 & 54.1 & 9.7 & 18.2 & 25 & 16.1 & 100 & 100 \\
\hline $\begin{array}{l}\text { Hungarians } \\
\text { in SK }\end{array}$ & 31 & 19.3 & 50 & 52.3 & 11 & 19.3 & 8 & 9.1 & 100 & 100 \\
\hline Total sample & 21 & 15.9 & 48.6 & 46 & 19.1 & 23.1 & 11.2 & 15 & 100 & 100 \\
\hline
\end{tabular}

BY, Belasus; LT, Lithuania; LV, Latvia; UA, Ukraine; PL, Poles; RU, Russia; SK, Slovakia; $18-29$ years, $\mathrm{n}=820 ; 30$ years and older, $\mathrm{n}=4,027$, in $\%$

\subsection{Image of and attitudes towards the $E U$}

For the question of image of the EU, the respondents were asked to rate their image on a scale of five (very positive, fairly positive, neutral, fairly negative, very negative). More than half of the young people reported their image as very or fairly positive $(13.3 \%$ very positive; $34.9 \%$ fairly positive). For another third, $33.6 \%$, the image was neutral, and only a small number stated that their image was fairly negative $(7.5 \%)$ or very negative $(2.5 \%){ }^{5}$

Comparing young people with adults, we found significant differences. In general, the young generation has a more positive image than the adult generation (mean for young people $=2.47$, mean for adults $=2.78, \mathrm{p}<0.001$,

${ }^{5}$ These results were already described in Waechter \& Samoilova (2012) 
two tailed) which confirms our hypothesis A4a. When analysing separately for the female and male population, we find that this cohort difference is true for both men and women.

Regarding gender, there is a slight tendency for young women to have a more positive image than young men $(r=0.150 ; p<0.001)$. The educational background does not make much difference; we have found a weak correlation $(\mathrm{r}=0.125 ; \mathrm{p}<0.001)$ meaning that those with a higher level of education are a little more likely to have a positive image of the EU. In our sample there are 12 ethnic minority groups from eight countries. Five of those countries are EU member states and three are not EU members (yet). However, regarding their image of the EU, it does not make any difference whether the respondents come from EU or non-EU member states.

The attitude towards the EU also differs between the ethnic groups researched. Three ethnic minority groups stand out because of their positive image (mean $=\sim 2.00$ ): the young generation of Poles in Ukraine, the Ukrainians in Poland, and the Hungarians in Slovakia profess to be more proEU. Their perception of the EU can be described as "fairly positive". These are the same groups who most reported being "very proud" of being European. The most negative image is documented by young Russians in Latvia (mean = 3.04). However, their perception should still labelled as "neutral".

Summarizing, the young cohort seems to have a generally positive or neutral attitude towards the EU, with only a few being very positive or fairly negative. Comparison of the young and older cohorts proves our hypothesis $\mathrm{A} 4 \mathrm{~b}$ that the minority youth cohort have more positive attitudes towards the EU than the adults have.

\subsection{Attitudes regarding their countries' (potential) benefit from being EU member}

In our total sample the respondents' image of the EU is highly correlated with their attitudes towards the (potential) benefit that their resident country has from being an EU member $(r=0.684, p=0.000)$. In the questionnaire we asked them using a scale of four (benefits a lot, rather benefits, rather does not benefit, does not benefit at all) whether they thought that their country benefits or does not benefit from being a member of the EU. Those respondents who live in countries without EU membership were asked if they thought that their country would or would not benefit.

Above all, we were interested in the young generation's attitudes in comparison to the adults. The majority of the young people interviewed think that their country of residence benefits (or would benefit) from being an EU member (benefits a lot $14.2 \%$, rather benefits $42.6 \%$ ). A third of the younger cohort across all researched minorities does not see benefits for their country of 
residence from being (becoming) an EU member (rather does not benefit $18.5 \%$, does not benefit at all $8.3 \%$ ). Compared with adults, young people are also just a little more positive in seeing benefits (mean for young people $=2.25$, mean for adults $=2.45, \mathrm{p}<0.001$, one-tailed), which confirms hypothesis A5.

Unlike the image the respondents have of the $\mathrm{EU}$, the attitude towards benefits does not depend on the educational level; neither is there a gender difference.

When we checked separately for each ethnic minority group, we received similar results as for the question regarding the image of the EU. A little more positive (towards the benefit impact of the EU) than the average among the young cohort across all ethnic groups were again the Poles in Ukraine, the Ukrainians in Poland, and the Hungarians in Slovakia. Russians in Latvia again were more sceptical than average, although, the Hungarians in Ukraine were the most sceptical group. In order to structure the results, we tried to group respondents with regard to their resident country's relation to the EU as well as to their ethnic group's home country's relation to the EU. With this perspective, we have formed three groups: both their resident country and their ethnic group's home country are EU members (e.g. Poles in Lithuania), their ethnic group's home country is an EU member but not their resident country (e.g. Hungarians in Ukraine); and their resident country is an EU member but not their ethnic group's home country (e.g. Russians in Lithuania). ${ }^{6}$ The results from descriptive analysis show that in the whole sample the relation of respondents' resident country and their ethnic group's home country to EU membership does not influence how they perceive possible EU benefits, nor does it influence their general image of the EU.

Whereas across all ethnic groups young people have a more positive image of the EU than adults, this effect is more diverse regarding the question of benefits: in three ethnic groups (Hungarians in Ukraine $\mathrm{p}<0.05$, Lithuanians in Russia $p>0.05$, Poles in Ukraine $p>0.05)$ young people are more sceptical about the positive impact on their (non-EU) country than the adult generation. However, only the difference in the case of Hungarians in Ukraine proved to be significant. Note that all three ethnic groups now live outside of the EU, whereas their ethnic home country has become an EU member. Therefore, one could assume that those respondents whose ethnic home country is an EU member state while their resident country is still a non-EU member might tend to show more EU scepticism than their parents' and grandparents' generations.

\footnotetext{
${ }^{6}$ Our sample did not include any respondents whose resident country and ethnic group's home country are both non-EU members.
} 


\subsection{The relationship between European, national and ethnic identity}

An examination of the Pearson correlations between European, national and ethnic identities provides us with insight into their compatibility for our respondents. In the first step, we checked correlations in the sets of the questions on how close our respondents feel to Europe, their receiving country, and their ethnic minority. In the second step, we examined correlations for the questions on pride.

In the total sample, European identity positively and significantly correlated with both national $(\mathrm{r}=0.296, \mathrm{p}<0.01$, one-tailed) and ethnic identity $(\mathrm{r}=$ $0.219, \mathrm{p}<0.01$, one-tailed). For the question on pride, European pride positively correlates with both national $(\mathrm{r}=0.170, \mathrm{p}<0.01$, one-tailed) and ethnic pride $(r=0.219, \mathrm{p}<0.01$, one-tailed $)$.

Among young people, European identity is positively correlated with both ethnic $(\mathrm{r}=0.149, \mathrm{p}<0.01$, one-tailed) and national identity $(\mathrm{r}=0.278, \mathrm{p}<$ 0.01 , one-tailed). Similar results were indicated for the pride item. European pride is positively correlated with both ethnic $(\mathrm{r}=0.231, \mathrm{p}<0.01$, one-tailed $)$ and national pride $(\mathrm{r}=0.098, \mathrm{p}<0.01$, one-tailed $)$.

In the adult group, European identity is positively and significantly related to ethnic $(r=0.238, p<0.01$, one-tailed) and national identity $(r=0.305, p<$ 0.01 , one-tailed). European pride is positively correlated with both ethnic $(\mathrm{r}=$ $0.228, \mathrm{p}<0.01$, one-tailed $)$ and national pride $(\mathrm{r}=0.180, \mathrm{p}<0.01$, one-tailed $)$.

The results support our hypotheses B and C. In addition, we observe that although for the two samples national identity has a stronger correlation with European identity in comparison to ethnic identity, in comparison to national pride, ethnic pride is found to be stronger related to European pride. These findings illustrate manifestation of different aspects of emotional attachment to Europe.

\section{Discussion and conclusions}

\subsection{European identity}

The results confirmed our first hypothesis and indicated that young people from ethnic minorities manifest a significantly stronger level of European identity than ethnic minority adults. The young cohort considers European identity to be more vital to their self-hood than does the older cohort and places it on the same level of importance as national identity. Minority young people have also reported significantly higher scores on closeness to Europe as well as European pride in comparison to the adults. Given these findings, it is not surprising that minority young people tend to have a more positive image of the EU and have more positive attitudes towards it. The results, therefore, show that what has been found for majority populations is also true for ethnic 
minority groups: the younger cohort tends to sympathize more with the EU and feel closer to Europe.

Our findings have also provided some new insights into existing literature on European identity. First, we have found that minority young people in the countries studied find their European identity just as salient as their national identity. This finding is very interesting, given the lack of literature on European identity among young people from ethnic minorities. For example, Cinnirella \& Hamilton (2007) discovered that in an overall sample of South Asian minorities in Britain, British national identity prevailed over European identity. However, their results did not show any significant difference for generational effect, which might be due to the small sample size. Our results suggest that minority young people might manifest very specific identity construction processes different from both majority and minority adults.

In addition, we have discovered that although the level of European identity is slightly decreasing with age, the level of ethnic and national identity among the youth cohort is significantly lower in comparison to the adults. This finding contradicts literature on linear integration of migrants and ethnic minorities suggesting that young members of minorities are expected to have stronger national identity and weaker ethnic identity. Therefore, we can suggest that European identity might influence the process of national acculturation. As we have suggested before, young people with a strong sense of ethnic belonging might find it easier to relate to a supra-national polity such as the EU, rather than a nation-state which is often based on an exclusive understanding of culture and history.

Our results also demonstrate some country-specific differences in young people's attitudes towards Europe and the EU. We have found that those young people who live outside the EU are more inclined to think that their ethnic group benefits from a possible EU membership than those who already live in an EU member state. This leads to the assumption that the ethnic young people researched, in general, hope for and expect support for their ethnic group from the EU, while for countries which have already become EU members their experience has shown less help than expected. Furthermore, we have found country-specific differences not only regarding EU membership but also regarding differences among the ethnic minority groups. Young people who belong to three particular ethnic groups have an especially positive image of the EU and also belong to those groups that are highly proud of being European: young Poles in Ukraine, young Ukrainians in Poland, and young Hungarians in Slovakia. 


\subsection{European, national, and ethnic identity}

The results supported our hypothesis regarding the relationship between European, ethnic and national identity. We found that among both young people and adults European identity is compatible with both national and ethnic identities. Moreover, national and ethnic identities have positive relationship with European identity. Here our research supported previous results (Cinnirella \& Hamilton, 2007) which showed that ethnic minorities' national identity is positively correlated with European identity. However, Cinnirella \& Hamilton (2007) did not find a significant correlation for ethnic and European identity. Our results show a high connection between ethnic and European identity among both young people and adults. Our results have shown a similar tendency for European pride. Both national and ethnic pride seem to be positively related to European pride. However, ethnic pride shows a stronger correlation.

The three groups of young people that stand out due to their especially positive image of the EU and a strong European pride, belong to ethnic minority groups who also show a very strong "ethnic minority identity": Ukrainians in Poland, Polish in Ukraine, and Hungarians in Slovakia. This confirms previous analysis of ENRI-VIS data which has shown that these groups are very proud of their ethnic home country and that they are proud of being part of their particular ethnic minority group living in that particular resident country (Chvorostov \& Waechter, 2011). The groups of young people who have the least European orientation - Russians in Latvia, Lithuanians in Russia, and Hungarians in Slovakia - belong to ethnic minority groups who are also less proud of being part of that particular ethnic minority group. Based on these results, we may assume that ethnic identity and pride are of particular relevance for the construction of European identity.

\section{REFERENCES}

Bauböck, R. (2000). European Integration and the Politics of Identity. ICE Working Paper Series No. 8. Vienna: Austrian Academy of Sciences, June 2000.

Brubaker, R., \& Cooper, F. (2000). Beyond "identity". Theory and Society. Renewal and Critique in Social Theory, 29(1), 1-47.

Chvorostov, A., \& Waechter, N. (2011). Moved peoples and moved borders: Research on the interplay of ethnic, national and regional identities in Central and Eastern Europe. Slovak Journal of Political Sciences, 11(3), 179-186.

Cinnirella, M. (1997). Toward a European identity? Interactions between the national and European social identities manifested by university students in Britain and Italy. British Journal of Social Psychology, 36, 19-31.

Cinnirella, M., \& Hamilton S. (2007). Are all Britons reluctant Europeans? Exploring European identity and attitudes to Europe among citizens of South Asian ethnicity. Ethnic and Racial Studies, 30(3), 481-501. 
Deutsch, F. (2006). Legitimacy and identity in the European Union: Empirical findings from the old member states. In I. P. Karolewski, \& V. Kaina (Eds.), European Identity: Theoretical Perspectives and Empirical Insights (pp. 149-178). Münster: LIT.

Eurobarometer (2005). Eurobarometer 62. Die öffentliche Meinung in der Europäischen Union. Retrieved from http://ec.europa.eu/public_opinion/archives/eb/eb62/eb_62.de.pdf

Fossum, J. E. (2001). Identity: Politics in the European Union. ARENA Working Papers, WP 01/17. Retrieved 25 January 2011 from http://www.arena.uio.no/publications/wp01_17.htm

Fuss, D., \& Grosser, M. A. (2006). What makes young Europeans feel European? Results from a cross-cultural research project. In I. P. Karolewski, \& V. Kaina (Eds.), European Identity: Theoretical Perspectives and Empirical Insights (pp. 209-243). Münster: LIT.

Hall, S., \& Du Guy, P. (Eds.) (1996). Questions of Cultural Identity. Thousand Oaks: Sage.

Herrmann, R., \& Brewer, M. B. (2004). Identities and institutions: Becoming European in the EU. In R. K. Herrmann, T. Risse, \& M. B. Brewer (Eds.), Transnational Identities: Becoming European in the EU (pp. 1-24). Lanham, MD: Rowman \& Littlefield.

Hofman, J.E. (1988). Social Identity and Intergroup conflict: An Israeli view. In W. Stroebe, A.W. Kruglanski, D. Bar-Tal, \& M. Hewstone (Eds.), The Social Psychology of Intergroup Conflict (pp. 89-102). New York: Springer Verlag.

Jamieson, L. (2005). Orientations of Young Men and Woman towards Citizenship and European Identity. Final Report of the EU funded project "Youth and European Identity". Retrieved 9 March 2011 from http://www.sociology.ed.ac.uk/youth/final_report.pdf ()

Jenkins, R. (1996). Social Identity. London: Routledge.

Karolewski, I. P., \& Kaina, V. (2006). European identity - Why another book on this topic? In I. P. Karolewski, \& V. Kaina (Eds.), European Identity: Theoretical Perspectives and Empirical Insights (pp. 11-22). Münster: LIT.

Kraus, P.A. (2008). A Union of Diversity. Language, Identity and Polity-Building in Europe. Cambridge: Cambridge University Press.

Mach, Z., \& Pozarlik, G. (2008). Collective identity formation in the process of EU Enlargement. Defeating the Inclusive Paradigm of a European Democracy? RECON Online Working Paper 2008/14. Retrieved 15 February 2010 from http://www.reconproject.eu/main.php/RECON_wp_0814.pdf?fileitem=16662557

Machácek, L. (2004). Young people in Bratislava and Prague: National and supranational identities. Sociológia, 36(6), 539-554.

Machácek, L. (2012). Slovak Republic and its Hungarian Ethnic Minority: Sociological Reflections, Slovak Journal of Political Sciences, 11(3), 187-210.

Örkény, A., \& Sik, E. (2011). Slovaks in Hungary. Slovak Journal of Political Sciences, 11(3), 211-228.

Spannring, R., Waechter, N., \& Datler, G. (2005). Neue Gemeinschaften - neue Identitäten? Eine Studie zu territorialen Identitäten Jugendlicher in der 
österreichisch-slowakischen Grenzregion. Final project report "New Communities - New Identities?" Vienna: Austrian Institute for Youth Research.

Tajfel, H. (1981). Human Groups and Social Categories. Cambridge: Cambridge University Press.

Tajfel, H., \& Turner, J. C. (1986). The social identity theory of inter-group behavior. In S. Worchel \& L. W. Austin (Eds.), Psychology of Intergroup Relations. Chicago: Nelson-Hall.

Waechter, N. (2012). Jugendkultur in der Krise? Eine Betrachtung von Jugendkulturen im Kontext der Arbeitsgesellschaft und sozialer Zugehörigkeit. Schulheft, 147(37), 34-44.

Waechter, N., \& Samoilova E. (2012). Attitudes towards Europe. Ethnical and national differences across Central and Eastern European border regions. In D. Arel, E. Pivovar, J. Radvanyi, \& V. Tishkov (Eds.), Twenty Years Later 1991 - 2011. The Reshaping of Space and Identity. The Proceedings of the International Congress Moscow, 29 September - 1 October 2011 (pp. 367-376). Moscow: Russian State University for the Humanities.

Natalia Waechter, is Professor in Social Pedagogy at the Department of Educational Science, University of Graz. Before, she was (senior)r researcher at the Institute for Advanced Studies, Vienna; the University of Eastern Finland, Joensuu; the University of California, Los Angeles (UCLA); and the Austrian Institute for Youth Research. Since 2010 she is European President of the Research Committee 34 (Sociology of Youth) of the International Sociological Association (ISA). She has published and carried out (international) research projects in the areas of youth research, studies on migration and ethnic minorities, political participation, and identity research.

Natalia Waechter

University Graz, Department of Educational Science, 8010 Graz, Merangasse 70

Austria

Email: natalia.waechter@uni-graz.at

Evgenia Samoilova is a PhD candidate in Bremen International Graduate School of Social Science. In her PhD project she addresses the issue of naturalization policies and integration experiences of immigrants via combining representative survey data and qualitative biographical interviews. Since 2013, she works as an academic staff member at Leibniz Institute for Social Science (GESIS) in Cologne. Along with her PhD project and interest in migration research, she has been actively involved in teaching qualitative, quantitative, and mixed methods to BA, MA and PhD students at Jacobs University Bremen. Her primary research interests include ethnicity, mixed methods, and methods education. 
Evgenia Samoilova

Leibniz Institute for Social Science (GESIS)

50667 Köln, Unter Sachsenhausen 6

Germany

Email: evgenia.samoilova@gesis.org 